\title{
Silage of residue from the extraction of cassava starch in diets from lactating holstein cows
}

\section{Silagem de resíduo da extração de amido da mandioca na dieta de vacas em lactação da raça holandesa}

\author{
Maximiliane Alavarse Zambom ${ }^{1}$; Tatiane Fernandes ${ }^{2 *}$; Emerson Luis Schmidt ${ }^{3}$; \\ João Arlindo Gouveia Gonçalves²; Magali Soares dos Santos Pozza'; Cleovani \\ Rossi Javorski²; Leiliane Cristine de Souza5; Rodrigo Cezar dos Reis Tinini²
}

\begin{abstract}
The objective of evaluating the intake and digestibility of nutrients, milk production, production efficiency and composition, and blood parameters of Holstein cows fed silage of the residue from the extraction of cassava starch (SRECS), replacing $0 \%, 25 \%, 50 \%, 75 \%$, or $100 \%$ of the corn feed. Cows with average production of $35 \mathrm{~kg}$ of milk a day were assigned in a $5 \times 5$ Latin square design, and for the 21 days trial period, they were housed in stalls and fed individually to control the dietary food, stool samples were performed to estimate the digestibility of nutrients. Milking were held twice a day, measuring the production and analysis of milk composition in each experimental period. Blood collections were performed at the end of each period to evaluate the metabolic condition of the cows. The data were analyzed using variance analysis and polynomial regression. The replacement of corn by SRECS did not affect the intake of dry matter (DM) or total carbohydrates (TC). There was a linear decrease in the intake of ether extract (EE), and a linear increase in the intake of neutral (NDF) and acid detergent fiber (ADF), indicating a quadratic regression with the intake of crude protein (CP). The use SRECS presented growing effect digestibility of the ADF, showing a positive linear effect. The total digestible nutrients (TDN) did not differ between the diets and had an average of $66.03 \%$. There was a trend of reduction $(10 \%)$ in the production, with consequent increase in delight in the concentration of its components. There was no change in the measured metabolites. The use of silage of the residue from the extraction of cassava starch to replace the ground corn on feed, negatively affects the nutrient intake without changing the efficiency of milk production, milk composition, in the same way as blood parameters of lactating cows.
\end{abstract}

Key words: Agro-industrial residue, blood parameters, cassava byproduct, dairy cattle, milk production, milk quality

\section{Resumo}

Objetivou-se avaliar o consumo e a digestibilidade dos nutrientes, produção, eficiência de produção e composição do leite e parâmetros sanguíneos de vacas da raça Holandesa alimentadas com silagem

1 Prof., Universidade Estadual do Oeste do Paraná, UNIOESTE, CCA, PPZ, Marechal Cândido Rondon, PR, Brasil. E-mail: mazambom@hotmail

2 Discentes do Programa de Pós-Graduação em Zootecnia/Mestrado, UNIOESTE, PPZ, Marechal Cândido Rondon, PR, Brasil. E-mail: tati-_tati@hotmail.com; joaoarlindo.gg@bol.com.br; cleo.rossi@hotmail.com; digotinini@hotmail.com

3 Zootecnista, UNIOESTE, CCA, Mal. Cândido Rondon, PR, Brasil. E-mail: emersonbs2@yahoo.com.br

4 Prof., UEM, DZO, PPZ, Maringá, PR, Brasil. E-mail: pozzamagali@yahoo.com.br

5 Discente do Programa de Pós-Graduação em Zootecnia/Doutorado, UEM, DZO, PPZ, Maringá, PR, Brasil. E-mail: leilics@ hotmail.com

* Author for correspondence 
do resíduo da extração da amido de mandioca (SREAM), substituindo $0 \%, 25 \%, 50 \%, 75 \%$ ou 100\% do milho da ração. As vacas com produção média de $35 \mathrm{~kg}$ de leite por dia, foram distribuídos em um delineamento em quadrado latino $5 \times 5$, com períodos de 21 dias, foram alojados em baias e alimentadas individualmente, para controlar a ingestão de alimentos, coletas de fezes foram realizadas para estimar a digestibilidade dos nutrientes. As ordenhas foram realizadas duas vezes ao dia, mensurando-se a produção e analisando a composição do leite em cada período experimental. Coletas de sangue foram realizadas ao final de cada período, para avaliar a condição metabólica das vacas. Os dados foram analisados por meio de análise de variância e de regressão polinomial. A substituição do milho por SREAM não afetou o consumo de MS e de carboidratos totais (CT). Houve redução linear na ingestão de extrato etéreo (EE), e um aumento linear na ingestão de fibra em detergente neutro (FDN) e fibra em detergente ácido (FDA), e apresentou uma regressão quadrática para a ingestão de proteína bruta (PB). O uso de SREAM apresentou efeito crescente para a digestibilidade da FDA. Os nutrientes digestíveis totais (NDT) não diferiram entre as dietas e apresentou média de $66,03 \%$. Houve uma tendência de redução (10\%) na produção deleite, com consequente aumento na concentração dos seus componentes. Não houve alteração nos metabolitos avaliados. O uso de silagem do resíduo da extração de amido da mandioca em substituição ao milho moído da ração, afeta negativamente a ingestão de nutrientes sem alterar a eficiência de produção e composição do leite, do mesmo modo que os parâmetros sanguíneos de vacas em lactação.

Palavras-chave: Bovinos de leite, parâmetros sanguíneos, produção de leite, qualidade do leite, resíduos da agroindústria, subprodutos da mandioca

\section{Introduction}

For milk production, feeding represents the majority of the variable costs and is associated with production profit or loss. Therefore, it is essential to search for alternative feeds that minimize the cost of feeding, while maximizing the producer's profits, thus enabling higher production and keeping them active in the market.

According to Pires et al. (2008), the use of alternative feed sources, such as agro-industrial residues, can contribute to reducing the production costs, as well as the possible environmental contamination these agro-industrial residues can cause. In this context, the cassava (Manihot esculenta Crantz), and its numerous byproducts resulting from industrial processing, stand out as cheaper energy substitutes for the ration formulation for ruminants, as they are a viable alternative because they have nutritional value similar to corn in the light of the high levels of non-structural carbohydrates (RAMALHO et al., 2006).

During the processing of the cassava, a solid residue is generated that is composed of fibrous material from the root and part of the starch that was not removed during the pressing process during the extraction of cassava starch by the humid method (BERTOL; LIMA, 1999; LEONEL et al., 1999). The production of crop cassava in July of 2013 was approximately 21178686 ton (IBGE, 2013). The starch production for each ton of processed roots is about $928.6 \mathrm{~kg}$ of residue with $85 \%$ moisture (LEONEL et al., 1999).

The residues that result from the industrial processing of cassava roots have energetic values similar to corn, and they are classified based on their energy sources for ruminant diets (CAVALCANTI, 2002; MARQUES et al., 2000; MARQUES; CALDAS NETO, 2002).

One of the problems associated with using the residue that results from the extraction of cassava starch (REAM) is the high humidity of the material, which makes it difficult to transport, store, and conserve. Silage being one of the conservation methods used for better use of this waste (GONÇALVES et al., 2014). Objective to evaluate the effects of inclusion of the inclusion of silage of cassava starch wet residue in the diet of milk cows on feed intake, nutrient digestibility, milk composition and production, milk efficiency, and blood parameters of Holstein cows. 


\section{Materials and Methods}

The experiment was conducted at the Universidade Estadual do Oeste do Paraná, Marechal Cândido Rondon Campus, Paraná, Brazil. The regional climate is mesothermal subtropical humid, with hot summers and infrequent frosts on winter. There is a tendency for a higher frequency of rains in the summer months, with no definite dry season. The average temperature for the warmest months is above $22{ }^{\circ} \mathrm{C}$, and for the coldest months, it is below $18^{\circ} \mathrm{C}$. The predominant relief is gentle hills, and the soil is classified as Oxisol (EMBRAPA, 2006).

Five multiparous Holstein cows, averaging $630.0 \mathrm{~kg}$ of body weight, $35.0 \mathrm{~kg}$ of milk production per day, and 150 days of milking were assigned in a Latin square design $(5 \times 5)$ for a total period of 105 days (14 days of adaptation and seven days for data and sample collection). The cows were fed different amounts $(0,250,500,750$ and $1000 \mathrm{~g} / \mathrm{Kg})$ of silage of residue from the extraction of cassava starch (SRECS), which replaced an equivalent amount of corn in their diet, those were the treatments. Their diet was composed of $50 \%$ corn silage as a source of roughage, and $50 \%$ of concentrate ration (corn, SRECS, soybean meal, and mineral supplement).

The wet residue was obtained from cassava starch in a production plant of Marechal Cândido Rondon city, and consisted of $128.0 \mathrm{~g} \mathrm{Kg}^{-1}$ of dry matter (DM), $25.3 \mathrm{~g} \mathrm{Kg}^{-1}$ of crude protein (CP), $25.0 \mathrm{~g} \mathrm{Kg}^{-1}$ of mineral matter (MM), $297.0 \mathrm{~g} \mathrm{Kg}^{-1}$ of neutral detergent fiber (NDF), and $06.1 \mathrm{~g} \mathrm{Kg}^{-1}$ of ether extract (EE), (based on the dry matter). This material was ensiled for about 40 days before the beginning of the experiment in concrete silos with a storage capacity of approximately one ton per silo. Once opened, the material had $189.8 \mathrm{~g} \mathrm{Kg}^{-1}$ of DM, $24.4 \mathrm{~g} \mathrm{Kg}^{-1}$ of CP, $23.8 \mathrm{~g} \mathrm{Kg}^{-1}$ of MM, $324.9 \mathrm{~g} \mathrm{Kg}^{-1}$ of NDF $\mathrm{g} \mathrm{Kg}^{-1}, 271.9 \mathrm{~g} \mathrm{Kg}^{-1}$ of ADF $\mathrm{g} \mathrm{Kg}^{-1}$, and 05.4 $\mathrm{g} \mathrm{Kg}^{-1}$ of EE (based on the dry matter).
The cows were housed in individual stalls during the feeding period, and each stall was equipped with a feeder for individual control of the diet. During the hottest hour of day and at night, the cows were released in the paddock to rest. The cows were fed twice a day, at $07 \mathrm{~h} 00$ and $18 \mathrm{~h} 00$, and were adjusted to 100 to $200 \mathrm{~g} \mathrm{Kg}^{-1}$ leftovers. The diets were formulated as recommended by the NRC (2001) to meet the requirements of the animals (Table 1).

During the seven day data collection period, samples of each diet and refusals were collected daily and pooled on a period basis. The samples were dried in a forced draught oven $\left(55^{\circ} \mathrm{C}\right.$ for $\left.72 \mathrm{~h}\right)$ and then ground through a $1 \mathrm{~mm}$ screen and packed in plastic pots for subsequent chemical analysis.

To determine the digestibility of the DM and nutrients, sample of feces were collected directly from the rectum ampule at the following times: 08h00, 10h00, 12h00, 14h00, 16h00, and $18 \mathrm{~h} 00$ from day 15 to 20 . To obtain estimates of fecal excretion, we used the indigestible NDF (NDFi) as a marker, as proposed by Cochran et al. (1986). The NDFi was estimated by incubating of TNT filters in the rumen of cattle, containing samples of feed, refusals, and feces, for 144 hours (WALLER et al., 1980). This was then followed by analysis of neutral detergent fiber using the method described by Detmann et al. (2001).

The samples of feed, refusals, and feces were analyzed to determine the content of DM according to AOAC (1980), MM, CP, and EE using the method described by Silva and Queiroz (2002). The contents of neutral detergent fiber (NDF) and acid detergent fiber (ADF) were determined using the method reported by Van Soest et al. (1991). The organic matter (OM) was estimated by the difference between the levels of total of MM and total DM. 
Table 1. Ingredients and chemical compositions of the diets.

\begin{tabular}{|c|c|c|c|c|c|}
\hline \multirow[b]{2}{*}{ Ingredient $\left(\mathrm{g} \mathrm{Kg}^{-1}\right)$} & \multicolumn{5}{|c|}{ Amount of SRECS $\left(\mathrm{g} \mathrm{Kg}^{-1}\right)$} \\
\hline & 0 & 250 & 500 & 750 & 1000 \\
\hline Corn silage & 500.0 & 500.0 & $\overline{500.0}$ & $\overline{500.0}$ & 500.0 \\
\hline SRECS & 0.0 & 55.8 & 132.5 & 200.0 & 247.5 \\
\hline Ground corn grain & 290.0 & 223.5 & 132.5 & 50.4 & 00.0 \\
\hline Soybean meal & 191.0 & 203.6 & 214.1 & 231.8 & 234.3 \\
\hline Vitamin minerals suplement ${ }^{1}$ & 15.0 & 13.3 & 16.4 & 13.3 & 13.3 \\
\hline Dicalcium phosphate & 2.0 & 2.0 & 2.7 & 2.7 & 3.1 \\
\hline Common salt & 2.0 & 1.8 & 1.8 & 1.8 & 1.8 \\
\hline \multicolumn{6}{|c|}{ Chemical composition ( $\mathrm{g} \mathrm{Kg}^{-1}$ of DM) } \\
\hline Dry matter $\left(\mathrm{g} \mathrm{Kg}^{-1}\right)$ & 609.2 & 567.2 & 514.6 & 467.8 & 433.3 \\
\hline Organic matter & 949.1 & 950.2 & 953.3 & 949.2 & 948.2 \\
\hline Crude protein & 160.2 & 161.5 & 159.7 & 164.3 & 161.3 \\
\hline Ether extract & 27.1 & 23.4 & 21.5 & 18.7 & 16.2 \\
\hline $\mathrm{TC}$ & 763.7 & 766.9 & 779.3 & 767.9 & 772.4 \\
\hline NDF & 345.4 & 368.0 & 395.1 & 423.6 & 411.8 \\
\hline $\mathrm{ADF}$ & 152.3 & 166.2 & 182.7 & 199.3 & 212.0 \\
\hline
\end{tabular}

SRECS: silage of residue from the extraction of cassava starch, TC: Total carbohydrates, NDF: neutral detergent fiber, and ADF: acid detergent fiber.

${ }^{1}$ Chemical composition (per kg of product): $260 \mathrm{~g} \mathrm{Ca}, 40 \mathrm{~g} \mathrm{P}, 13 \mathrm{mg} \mathrm{Co}, 15 \mathrm{~g} \mathrm{Mg}, 1100 \mathrm{mg} \mathrm{Mn,} 3000 \mathrm{mg} \mathrm{Zn,} 20 \mathrm{mg} \mathrm{Se,} 40 \mathrm{mg} \mathrm{I}$, $12 \mathrm{~g} \mathrm{~S}, 170 \mathrm{mg} \mathrm{Fe}, 400 \mathrm{mg} \mathrm{Fe}$, and $1000 \mathrm{mg}$ of Lasalocid (commercial product).

Cows were weighed on the first day and then every 21 days during each experimental period immediately after milking and prior to being fed in the morning. Milking was performed twice a day (06h00 and 18h00) and recorded daily from day 15 to 21 during each experimental period. To analyze the composition of the milk, samples were collected (06h00 and 18h00) from the four consecutive milkings on days 15 and 16 of each experimental period.

The chemical analyses of the milk samples were performed to determine the levels of fat, protein, lactose, nonfat solids, total solids, and minerals using the automatic analyzer Milkoscope ${ }^{\circledR}$. The milk production was corrected to $3.5 \%$ of fat (MPC), by the equation proposed by Sklan et al. (1992):

$\mathrm{MPC}=(0.432+0.1625 \times \mathrm{G}) \times \mathrm{kg}$ of milk

Where $\mathrm{G}$ is the $\%$ of milk fat.

The feed efficiency for each cow was defined as the ratio between the average milk production and the average DM intake during each period of data collection (VALADARES FILHO et al., 2000).
Blood samples were taken immediately after milking and before the morning feeding on the day 21 of each data collection period using $10 \mathrm{~mL}$ test tubes and by puncturing the mammary vein. The samples were refrigerated and sent to the laboratory for processing and analysis. The plasma was obtained by centrifugation at $3500 \mathrm{rpm}$ for 15 minutes. This was then used to determine the concentrations of glucose and urea using commercial kits by the colorimetric method. Briefly, an aliquot of the centrifuged material was added to reagent of each kit for further analysis using a spectrophotometer.

The data were analyzed using analysis of variance and polynomial regression taking into account the levels of silage from cassava starch $(0 \%, 25 \%, 50 \%$, $75 \%$, or $100 \%$ ) at the level of $5 \%$ of probability.

\section{Results and Discussion}

Corn is usually used as an energy feed source for dairy cows. In this study, we evaluated the use of SRECS, in place of corn, verifying significant 
differences $(\mathrm{P}<0.05)$ for the intake of dry matter (DMI), crude protein (CPI), ether extract (EEI), total carbohydrates (TCI), neutral detergent fiber (NDFI), acid detergent fiber (ADFI), and total digestible nutrients (INDT), as shown in Table 2. The DMI as a percentage of body weight was not influenced by the substitution of corn by SRECS, with an average of $3.70 \%$ of IMS/body weight.

Table 2. Intake of DM and nutrients of the ration by lactating cows receiving SRECS in place of ground corn.

\begin{tabular}{|c|c|c|c|c|c|c|c|c|c|}
\hline \multirow{2}{*}{$\left(\mathrm{kg} \mathrm{DM}^{-1} \mathrm{~d}^{-1}\right)$} & \multicolumn{5}{|c|}{ SRECS $\left(\mathrm{g} \mathrm{Kg}^{-1}\right)$} & \multirow{2}{*}{$\mathrm{CV}$} & \multicolumn{3}{|c|}{$P$ value ${ }^{1}$} \\
\hline & 0 & 250 & 500 & 750 & 1000 & & $\mathrm{~L}$ & $\mathrm{Q}$ & $\mathrm{C}$ \\
\hline$\overline{\mathrm{DMI}^{2}}$ & 24.31 & 23.31 & 24.55 & 21.49 & 23.10 & 1.847 & 0.000 & 0.229 & 0.001 \\
\hline $\mathrm{CPI}^{3}$ & 3.88 & 3.78 & 3.78 & 3.62 & 3.79 & 2.010 & 0.009 & 0.014 & 0.061 \\
\hline $\mathrm{EEI}^{4}$ & 0.61 & 0.51 & 0.49 & 0.38 & 0.34 & 6.121 & 0.000 & 0.438 & 0.776 \\
\hline $\mathrm{TCI}^{5}$ & 18.60 & 18.06 & 19.13 & 16.38 & 17.79 & 2.160 & 0.000 & 0.930 & 0.000 \\
\hline $\mathrm{NDFI}^{6}$ & 5.44 & 5.27 & 6.28 & 5.92 & 6.43 & 6.787 & 0.001 & 1.000 & 0.601 \\
\hline $\mathrm{ADFI}^{7}$ & 3.58 & 3.76 & 4.38 & 4.15 & 4.76 & 2.723 & 0.000 & 0.930 & 0.024 \\
\hline $\mathrm{NDTI}^{8}$ & 16.24 & 15.20 & 16.41 & 14.14 & 14.68 & 3.361 & 0.000 & 0.707 & 0.448 \\
\hline
\end{tabular}

DMI: dry matter intake; CPI: crude protein intake; EEI: ether extract intake; TCI: total carbohydrates intake; NDFI: neutral detergent fiber intake; ADFI: acid detergent fiber intake; and NDTI: digestible nutrients overall intake

${ }^{1} \mathrm{~L}, \mathrm{Q}$, and C: linear, quadratic, and cubic order effects, relative to SRECS levels

${ }^{2} \mathrm{Y}=24,1981-0.0169654 \mathrm{x}\left(\mathrm{R}^{2}=0.31\right) ;{ }^{3} \mathrm{Y}=3.388719-0.00546335 \mathrm{x}+0.0000413391 \mathrm{x}^{2}\left(\mathrm{R}^{2}=0.60\right) ;{ }^{4} \mathrm{Y}=0.597511-0.00268637 \mathrm{x}$ $\left(\mathrm{R}^{2}=0.96\right) ;{ }^{5} \mathrm{Y}=18.6520-0.0132129 \mathrm{x}\left(\mathrm{R}^{2}=0.25\right) ;{ }^{6} \mathrm{Y}=5.33971+0.0105642 \mathrm{x}\left(\mathrm{R}^{2}=0.67\right) ;{ }^{7} \mathrm{Y}=3.57836+0.0109318 \mathrm{x}\left(\mathrm{R}^{2}=\right.$ $0.84) ;{ }^{8} \mathrm{Y}=16.1681-0.0166573 \mathrm{x}\left(\mathrm{R}^{2}=0.45\right)$.

The DMI values adjusted linear regression and cubical, however, there is no biological explanation for the cubic variation. The linear effect is due to the starch from cassava have faster fermentation in the rumen as compared to corn starch, which results in an increase in the amount of volatile fatty acids (VFA's) formed in the rumen, especially the propionate (SVIHUS et al., 2005). Which leads to restriction of intake in response to metabolic signal of satiety due to the oxidation of propionate in the liver (ALLEN, 2000). Mouro et al. (2002) observed an increase in the degradability of diets with increasing amounts of cassava byproduct on meal, a food with composition similar to SRECS when compared in DM. Despite the NDF content be elevated in the diet, it is likely that has not influenced the DMI, once the NDF from SRECS does not limit consumption, by not owning physical effectivity, which occurs with NDF from agro waste (PEREIRA et al., 1999).

The quadratic effect $(\mathrm{P}<0.05)$ has been observed for crude protein intake (CPI; Table 2), being this explained by differences in chemical composition in the experimental diet, associated to intake of DM. There was a positive linear effect $(\mathrm{P}<0.05)$ due to the replacement of corn with SRECS in the intake of NDF and ADF (Table 2). As the replacement levels increased, there was a greater amount of SRECS, which is characterized as a fibrous material from the root and hulls of the cassava, thus providing an increased fraction of NDF and ADF in the diet fed to animals, and resulting in the increased intake of NDF and ADF. The differences in NDF and ADF consumption between the treatments can be explained by the different levels of the fractions in the diets and by the intake of DM obtained in each treatment. Lima et al. (2008) reported a reduction in consumption of ADF with the increase of REAM, while the REAM consumption did not differ between the treatments.

The decrease in EE intake $(\mathrm{p}<0.05)$ was due to the increase in soybean meal in the diet and the decreased percentage of corn. Soybean meal contains low levels of EE, thus providing a lower 
content of EE in the offered diet (Table 1). In this study, we found lower concentrations of EE in the total diet with the increased addition of SRECS, thereby providing for a linear effect on IEE. Similar results were reported by Lima et al. (2008) when they evaluated the inclusion of RESC in the diet of cows on 150 days of lactation, due to the low lipid content $(0.60 \%)$ of REAM. For the NDTI linear reduction obtained with increasing substitution of SRECS, according to the reduction in DMI, but stuck close to the values recommended by NRC (2001).

There were no significant differences in the coefficients of apparent digestibility of DM, CP, EE, $\mathrm{TC}$, and NDF in the diets of lactating cows receiving SRECS in place of corn. However, the digestibility coefficient from the acid detergent fiber showed a positive linear effect with the increase of SRECS in the diet (Table 3).

Table 3. Digestibility coefficients of DM and nutrients from feed rations of lactating cows receiving SRECS in place of ground corn.

\begin{tabular}{|c|c|c|c|c|c|c|c|c|c|}
\hline \multirow{2}{*}{$\left(\mathrm{g} \mathrm{Kg}^{-1}\right)$} & \multicolumn{5}{|c|}{ SRECS $\left(\mathrm{g} \mathrm{Kg}^{-1}\right)$} & \multirow{2}{*}{$\mathrm{CV}$} & \multicolumn{3}{|c|}{$\mathrm{P}$ value $^{1}$} \\
\hline & 0 & 250 & 500 & 750 & 1000 & & $\mathrm{~L}$ & Q & $\mathrm{C}$ \\
\hline$\overline{\mathrm{DMD}}$ & 660.7 & 640.7 & 654.2 & 649.7 & 642.5 & 2.926 & 0.331 & 0.820 & 0.198 \\
\hline OMD & 682.6 & 662.4 & 684.2 & 678.1 & 658.6 & 2.514 & 0.202 & 0.367 & 0.040 \\
\hline CPD & 658.1 & 644.4 & 649.0 & 672.2 & 648.0 & 3.404 & 0.812 & 0.957 & 0.059 \\
\hline EED & 659.6 & 648.9 & 681.2 & 706.3 & 601.8 & 6.202 & 0.611 & 0.166 & 0.148 \\
\hline TCD & 687.0 & 665.9 & 690.6 & 678.6 & 660.9 & 2.722 & 0.154 & 0.349 & 0.071 \\
\hline NDFD & 422.6 & 428.0 & 467.5 & 469.8 & 478.8 & 11.212 & 0.053 & 0.730 & 0.710 \\
\hline $\mathrm{ADFD}^{2}$ & 413.7 & 426.7 & 470.4 & 482.1 & 516.2 & 10.479 & 0.003 & 0.901 & 0.905 \\
\hline TDN & 681.9 & 664.2 & 683.5 & 677.7 & 659.0 & 2.601 & 0.216 & 0.371 & 0.067 \\
\hline
\end{tabular}

DMD: digestibility dry matter; CPD: digestibility of crude protein; EED: digestibility of ether extract; TCD: digestibility of total carbohydrates; NDFD: digestibility of neutral detergent fiber; ADFD: digestibility of acid detergent fiber; and TDN: total digestible nutrients

${ }^{1} \mathrm{~L}, \mathrm{Q}$, and C: linear, quadratic, and cubic order effects, relative to SRECS levels ${ }^{2} \mathrm{Y}=46.18+0.10 \mathrm{x}\left(\mathrm{R}^{2}=0.67\right)$.

The substitution of corn by SRECS did not influence the DM digestibility $(\mathrm{P}>0.05)$ of diets, with an average of $64.96 \%$. These results are in agreement with those reported by Mouro et al. (2002), in which they used a different residue of processing of the cassava in feed for dairy cattle.

The digestibility of OM, which had cubic variation $(\mathrm{P}<0.05)$, was probably due to interactions between the ingredients used and the associated with the process of rumen fermentation. The digestibility coefficient of EE was similar to that reported by Abrahão et al. (2006), who found average DEE value of $67.72 \%$ in diets containing RESC at different levels, for young bulls on termination.
A positive linear trend was observed for the NDF digestibility as the SRECS in the diet increased (P $=0.053$ and $\mathrm{R} 2=0.88$ ). This verified that with $100 \%$ substitution, the digestibility coefficient of NDF was $47.88 \%$, and with $0 \%$ substitution, the value was $42.26 \%$. These results can be attributed to the characteristics of the fibrous fractions of REAM, which is characterized by having $89.44 \%$ of the soluble fraction or rapidly degradable fraction and $9.93 \%$ of slowly degradable and $0.69 \%$ of indigestible fraction (FERREIRA et al., 2007). The positive linear effect $(\mathrm{P}<0.05)$ observed for the ADF digestibility coefficient can be partially attributed to the high content of cellulose and lower level of hemicellulose contained in the cell wall, 
which promotes reduced digestibility by preventing the microorganism action. The SRECS contains high content of NDF (32.5\%) and FDA (27.19\%), however, this material is finely ground, allowing greater access of ruminal microorganisms to the fibrous fraction, allowing a greater degradation and consequent increase in digestibility, associated with the greatest length of stay in the rumen as a consequence of reduced consumption.

The total digestible nutrients (TDN) was similar between the treatments $(\mathrm{P}>0.05)$, averaging $66.03 \%$. These results are similar to those obtained by Abrahão et al. (2006), who showed that the replacement of corn by the cassava residue in the feeding of young bulls on termination had an average DTN of $65.47 \%$. Dias et al. (2008) found a linear reduction $(\mathrm{P}<0.05)$ of NDT when studying the inclusion of $0 \%, 7 \%, 14 \%$, and $21 \%$ of cassava starch in the feed of dairy heifers, giving values of $68.0 \%, 66.2 \%, 67.0 \%$, and $62.5 \%$, respectively.
Did not obtain significant results for milk production, but a tendency towards reduction of production (P 0.094) was observed with increased replacement of corn for SRECS (table 4), probably due to the reduction in DMI without effect on the digestibility of nutrients. Similar to this study Ramalho et al. (2006) when evaluating the replacement of corn by the cassava starch for Holstein cows with an average milk production of 24 liters per day and body weight of $450 \mathrm{~kg}$. They found a negative linear effect $(\mathrm{P}<0.05)$, and attributed this variation to the differences in the processes of digestion, absorption, and metabolism (fast degradation of starch cassava, reduction of rumen $\mathrm{pH}$ ) between the corn starch and cassava, and with the associative effects of these feeds to the other ingredients in the diet.

Table 4. Averages, coefficients of variation (CV) for milk production (MP), milk production efficiency (MPE), and milk components from lactating Holstein cows receiving silage of residue from the extraction of cassava starch, replacing the ground corn from the ration.

\begin{tabular}{|c|c|c|c|c|c|c|c|c|c|}
\hline \multirow{2}{*}{ Variables } & \multicolumn{5}{|c|}{ SRECS $\left(\mathrm{g} \mathrm{Kg}^{-1}\right)$} & \multirow{2}{*}{$\mathrm{CV}$} & \multicolumn{3}{|c|}{ P value ${ }^{1}$} \\
\hline & 0 & 250 & 500 & 750 & 1000 & & $\mathrm{~L}$ & $\mathrm{Q}$ & $\mathrm{C}$ \\
\hline $\mathrm{MP}\left(\mathrm{kg} \mathrm{dia}^{-1}\right)$ & 35.07 & 33.83 & 33.03 & 31.86 & 31.56 & 6.690 & 0.094 & 0.396 & 0.975 \\
\hline MPE & 1.44 & 1.46 & 1.35 & 1.48 & 1.36 & 7.320 & 0.719 & 0.848 & 0.228 \\
\hline Fat $\left(\mathrm{g} \mathrm{Kg}^{-1}\right)^{2}$ & 3.55 & 3.99 & 3.54 & 3.88 & 4.04 & 5.899 & 0.020 & 0.554 & 0.044 \\
\hline Protein $\left(\mathrm{g} \mathrm{Kg}^{-1}\right)^{3}$ & 3.14 & 3.13 & 3.15 & 3.20 & 3.24 & 1.748 & 0.005 & 0.220 & 0.654 \\
\hline Lactose $\left(\mathrm{g} \mathrm{Kg}^{-1}\right)^{4}$ & 4.69 & 4.68 & 4.71 & 4.79 & 4.84 & 1.743 & 0.005 & 0.237 & 0.623 \\
\hline Minerals $\left(\mathrm{g} \mathrm{Kg}^{-1}\right)^{5}$ & 0.71 & 0.70 & 0.71 & 0.72 & 0.73 & 1.681 & 0.005 & 0.187 & 0.528 \\
\hline $\mathrm{DS}\left(\mathrm{g} \mathrm{Kg}^{-1}\right)^{6}$ & 8.53 & 8.53 & 8.58 & 8.71 & 8.81 & 1.778 & 0.005 & 0.265 & 0.672 \\
\hline $\mathrm{TS}\left(\mathrm{g} \mathrm{Kg}^{-1}\right)^{7}$ & 12.09 & 12.52 & 12.12 & 12.59 & 12.85 & 1.865 & 0.000 & 0.198 & 0.084 \\
\hline
\end{tabular}

DS: solids nonfat; and TS: total solids

${ }^{1} \mathrm{~L}, \mathrm{Q}$, and $\mathrm{C}$ : linear, quadratic, and cubic order effects, relative to SRECS levels

${ }^{2} \mathrm{Y}=3.6294+0.0034\left(\mathrm{R}^{2}=0.32\right) ;{ }^{3} \mathrm{Y}=3.116+0.001072 \mathrm{x}\left(\mathrm{R}^{2}=0.86\right) ;{ }^{4} \mathrm{Y}=4.6624+0.001608\left(\mathrm{R}^{2}=0.87\right) ;{ }^{5} \mathrm{Y}=0.70+0.000232 \mathrm{x}$ $\left(\mathrm{R}^{2}=0.83\right) ;{ }^{6} \mathrm{Y}=8.4818+0.003008 \mathrm{x}\left(\mathrm{R}^{2}=0.88\right) ;{ }^{7} \mathrm{Y}=12.1112+0.006408 \mathrm{x}\left(\mathrm{R}^{2}=0.60\right)$

In this study we did not observe variation in milk production, but did observe variations in the percentages of the various milk constituents. This is not surprising since the milk yield is related to the ingestion of water, and it is likely that the high content of water present in SRECS reduced the intake of water and, therefore, had an influence on the concentration of the milk components. Brasil et al. (2000) observed that animals under thermal stress doubled their water consumption, 
resulting in reduced milk components, such as fat, protein, lactose, and total solids. The results in this study disagree with those reported by Nocek and Taminga (1991), who attribute the reduction in milk production to the rate of ruminal degradation of starch from corn, since the largest portion is degraded in the small intestine and the glucose absorbed in the small intestine would be better utilized by ruminants for the production of milk.

The efficiency of milk production was not significantly influenced $(\mathrm{P}>0.05)$. According to Assis et al. (2004), the consumption of feed determines the level of nutrient intake and, thus, the animal's performance. In the present study it was observed a reduction in DMI without amendment on nutrient digestibility, which led to a trend towards reduction in milk production without affecting the efficiency of milk production.

In this study, there was a linear positive difference the in fat content $(\mathrm{P}<0.05)$ of the milk until $100 \%$ of the corn was substituted by SRECS, thereby altering one of the main components of the milk. This effect is likely associate with the increase in digestibility of NDF, when the corn was replaced by SRECS, which provides greater energy supply to the animal, providing increase in milk fat content, since maintaining the quality of fiber it can increasing this component in the milk (LAMMERS et al., 1996).

The final products of fermentation of carbohydrates in the rumen are mainly acetate, propionate, and butyrate. The subsequent metabolism of volatile fatty acids (VFA) constitutes the major energy source for ruminants, which may represent up to $80 \%$ of the daily energy requirements of the animals (VAN SOEST, 1994). The use of SRECS could possibly alter the VFA concentration in the blood due to the increased of NDF on diet (Table 1), and the higher degradability of the starch derived from cassava could influence fat synthesis in the mammary gland.

Increasing the level of corn substitution by
SRECS resulted in a positive linear effect on the content of protein in the milk $(\mathrm{P}<0.05)$. Probably for increasing microbial protein synthesis in the rumen, improving the profile of amino acids in the metabolizable protein flow, as a function of greater digestibility of the NDF, when the highest levels of SRECS were used. According to Santos et al. (1998), as the degradability of the starch increases, there is an increase in protein content in the milk, perhaps due to the increase of microbial synthesis, leading to an increase in the metabolizable protein flow to the intestine, improving the profile of essential amino acids. These results disagree with those reported by Pires et al. (2008), they found that the conversion efficiency from the feed into protein in the milk was lower for the cassava starch, another product with a similar composition to SRECS.

Lactose plays an important role in the synthesis of milk. Not only is it the main osmotic factor in milk, responsible for $50 \%$ of this variable, but it "attracts" water to the mammary epithelial cells during the process of milk synthesis. Due to the close relationship between lactose synthesis and the amount of water drained into the milk, the lactose content of the milk has minimal variation (GONZÁLEZ, 2001a). However, in our study, we observed that there was a positive linear variation $(\mathrm{P}<0.05)$ with increased SRECS content, while the milk production had negative linear variation $(\mathrm{P}<0.05)$.

The synthesis of lactose in the mammary gland is dependent on the availability of glucose, which is highly dependent on the availability of gluconeogenic precursors in the liver, since there is no positive net flow of glucose into the portal vein due to the intensive use by visceral tissues (rumen, intestine, pancreas and spleen) of glucose absorbed from the intestine. The utilization of more starch sources with higher rumen degradability results in increased availability from the main precursors for hepatic gluconeogenesis, the propionate, amino acids, and lactate (HUNTINGTON, 1997; THEURER et al., 1999). It is possible that SRECS 
utilization resulted in an increase in the supply of starch with higher rumen degradability, resulting in a greater production of gluconeogenic precursors and, consequently, an increase in available glucose in the mammary gland, thus increasing lactose production. Expected an increase in milk production with an increase in the synthesis of lactose. The lactose acts as main osmotic factor from milk, attracting water into the mammary gland, however, lactose corresponds with only $50 \%$ of this variable, thus other factors involved in the osmolarity of milk like potassium, sodium and chloride, may have been reducing the permeability of water in the mammary gland (GONZÁLEZ, 2001a).

The levels of minerals changed linearly $(\mathrm{P}<0.05)$ with the increase in SRECS substitution for corn, maybe by the relation of lactose with the minerals present in milk. The milk from healthy animals has a constant content of lactose, potassium, and sodium. The concentration of each component represents an individual constant. Also, in each breed, a very precise relationship between the concentration of lactose and the sum of the molar concentrations of sodium and potassium, as well as an inverse relationship between the content of lactose and potassium, has been observed (GONZÁLEZ, 2001a).

According to González et al. (2001a) the milk is in osmotic equilibrium with the blood and the osmotic pressure from the milk, which is dependent upon the content of lactose, sodium, potassium, and chloride, which favors the entry of water into the mammary epithelial cell to produce the milk and partially controls the volume of milk produced. The lactose concentration has a small range of variation since it is related to the osmotic pressure in the mammary gland, and an increased production of lactose allows for greater milk production. This was not observed in this present study, however. We detected a positive change in lactose and minerals, while a negative variation for milk production was observed. There was probably an imbalance between the osmotic pressure of the blood and the osmotic pressure of the milk, possibly due to the percentage of feed moisture (SRECS, with approximately $85 \%$ of moisture), which may have caused a reduction in water intake and absorption.

We observed a positive linear variation $(\mathrm{P}<0.05)$ for the levels of nonfat solids and total solids, mainly due to the levels of protein, lactose, and minerals. According to González et al. (2001a), the variations in the solids can be better explained by the variations in the components. The variation in the total solids content (fat + protein + lactose + minerals) is, for the most part, dependent on variations in the fat content of the milk fraction, which has a greater degree of variation. For nonfat solids, protein may be the only component capable of variation as a function of nutrition. However, in this study there was detectable variation in the levels of protein, lactose and minerals.

The substitution of corn by SRECS did not result in differences $(\mathrm{P}>0.05)$ in body weight. Demonstrating that the energy ingested by animals was used for milk production, and infer that the animals who consumed high levels of SRECS not expressed as much of your genetic potential in terms of reduction of DMI.

The plasma glucose concentration did not differ $(\mathrm{P}>0.05)$ between the treatments (Table 5). This is similar to a report by Pires et al. (2008), who found no difference in plasma glucose concentrations in animals fed cassava starch as a source of starch. The plasma concentration of urea did not differ $(\mathrm{P}>0.05)$ between treatments, showing that the efficiency of protein utilization was not influenced by the substitution of corn by SRECS. According to González et al. (2001b), the level of blood glucose showed little variation due to very efficient homeostatic mechanisms of the organism. Approximately 70 circulating glucose is used, through the endergonic process for the synthesis of lactose in milk (GONZÁLEZ et al., 2001a). They stated that the diet has little influence on glycemia, except in animals with severe malnutrition. 
Table 5. Averages, regression equations, and coefficients of determination (R2) and variation (CV) for body weight, blood glucose, and plasma urea nitrogen (PUN) from lactating Holstein cows receiving SRECS in place of ground corn

\begin{tabular}{|c|c|c|c|c|c|c|c|c|c|}
\hline & \multicolumn{5}{|c|}{ SRECS (g/Kg) } & \multirow[t]{2}{*}{$\mathrm{CV}$} & \multicolumn{3}{|c|}{$\mathrm{P}$ value $^{1}$} \\
\hline & 0 & 250 & 500 & 750 & 1000 & & $\mathrm{~L}$ & $\mathrm{Q}$ & $\mathrm{C}$ \\
\hline Body weight (kg) & 630.0 & 629.0 & 625.0 & 621.0 & 638.0 & 3.077 & 0.774 & 0.288 & 0.397 \\
\hline Glucose $\left(\mathrm{mg} \mathrm{dl}^{-1}\right)$ & 42.31 & 40.91 & 41.98 & 39.10 & 39.86 & 15.088 & 0.456 & 0.975 & 0.895 \\
\hline PUN $\left(\mathrm{mg} \mathrm{dL}^{-1}\right)$ & 21.16 & 19.33 & 18.49 & 19.73 & 20.66 & 16.416 & 0.895 & 0.189 & 0.783 \\
\hline
\end{tabular}

${ }^{1} \mathrm{~L}, \mathrm{Q}$, and C: linear, quadratic, and cubic order effects, relative to SRECS content

The levels of urea nitrogen in the plasma remained within the acceptable range for lactating cows, which ranges between $7 \mathrm{mg} \mathrm{dL}^{-1}$ and $23.5 \mathrm{mg}$ $\mathrm{dL}^{-1}$ (LIMA et al., 2008). Urea is synthesized in the liver in amounts proportional to the concentration of ammonia produced in the rumen, and its blood concentration is directly related to the feed and protein levels from the ration and to the relationship of the energy/protein provided by the diet (GONZÁLEZ et al., 2000). The blood urea levels are affected by the nutritional status, particularly in the ruminants, serving as an immediate and sensitive indicator of protein intake (GONZÁLEZ et al., 2001b).

The use of the SRECS to replace ground corn in the feed of cows promotes a negative linear effect on the DM intake, however, does not affect the digestibility of DM and nutrients, efficiency of milk production, milk composition, and the blood parameters of lactating cows.

\section{References}

ABRAHÃO, J. J. S.; PRADO, I. N.; PEROTTO, D.; ZEOULA, L. M.; LANÇANOVA, J. A. C.; LUGÃO, S. M. B. Digestibilidade de dietas contendo resíduo úmido de mandioca em substituição ao milho para tourinhos em terminação. Revista Brasileira de Zootecnia, Viçosa, MG, v. 35, n. 4, p. 512-518, 2006.

ALLEN, S. A. Effects of diet on short-term regulation of feed intake by lactating dairy cattle. Journal Dairy Science, Philadelphia, v. 83, n. 7, p. 1598-1624, 2000.

ASSIS, A. J.; CAMPOS, J. M. S.; VALADARES, S. C. F.; QUEIROZ, A. C.; LANA, R. P.; EUCLYDES,
R. F.; MENDES NETO, J.; MAGALHÃES, A. L. M.; MENDONÇA, S. S. Polpa cítrica em dietas de vacas em lactação. 1. Consumo de nutrientes, produção e composição do leite. Revista Brasileira de Zootecnia, Viçosa, MG, v. 33, n. 1, p. 242-250, 2004.

ASSOCIATION OF OFFICIAL ANALYTICAL CHEMISTRY - AOAC. Official methods of analysis. $13^{\text {th }}$ Ed. Washington D. C.: Association of Analytical Chemistry, 1980. 384 p.

BERTOL, T. M.; LIMA, G. J. M. M. Níveis de resíduo industrial de fécula da mandioca na alimentação de suínos em crescimento e terminação. Pesquisa Agropecuária Brasileira, Brasília, v. 34, n. 2, p. 243-248, 1999.

BRASIL, L. H. A.; WECHESLER, F. S.; BACCARI JÚNIOR, F.; GONÇALVES, H. C.; BONASSI, I. A. Efeitos do estresse térmico sobre a produção, composição química do leite e respostas termorreguladoras de cabras da raça alpina. Revista Brasileira de Zootecnia, Viçosa, MG, v. 29, n. 6, p. 1632-1641, 2000.

CAVALCANTI, J. Perspectivas da mandioca na região semi-árida do Nordeste. EMBRAPA: Rumos e Debates, 2002. Disponível em: <http://www.embrapa.br/imprensa/ artigos/.../artigo.2004-12-07.260791828>. Acesso em: 19 set. 2011.

COCHRAN, R. C.; ADAMS, D. C.; WALLACE, J. D. et al. Predicting digestibility of different diets with internal markers: evaluation of four potential markers. Journal of Dairy Science, Philadelphia, v. 63, n.5, p. 1476-1483, 1986.

DETMANN, E.; PAULINO, M. F.; ZERVOUDAKISI, J. T.; VALADARES FILHO, S. C.; EUCLYDES, R. F.; LANA, R. P.; QUEIROZ, D. S. Cromo e indicadores internos na determinação do consumo de novilhos mestiços, suplementados, a pasto. Revista Brasileira de Zootecnia, Viçosa, MG, v. 30, n. 5, p. 1600-1609, 2001.

DIAS, A. M.; SILVA, F. F.; VELOSO, C. M.; ÍTAVO, L. C. V.; PIRES, A. J. V.; DAMASCENO, J. C.; SOUZA, D. R.; SÁ, J. F.; NASCIMENTO, P. V. N.; MACHADO, E. 
F. Digestibilidade dos nutrientes do bagaço de mandioca em dietas de novilhas leiteiras. Arquivo Brasileiro de Medicina Veterinária e Zootecnia, Belo Horizonte, v. 60, n. 4, p. 996-1003, 2008.

EMPRESA BRASILEIRA DE PESQUISA AGROPECUÁRIA - EMBRAPA. Sistema brasileiro de classificação de solos. 2. ed. Rio de Janeiro: Embrapa, 2006. $412 \mathrm{p}$.

FERREIRA, G. D. G.; OLIVEIRA, R. L.; CARDOSO, E. C.; MAGAlHÃeS, A. L. R.; BRITO, E. L. Valor nutritivo de co-produtos da mandioca. Revista Brasileira de Saúde e Produção Animal, Salvador, v. 8, n. 4, p 364374, 2007.

GONÇALVES, J. A. G.; ZAMBOM, M. A.; FERNANDES, T.; MESQUITA, E. E.; SCHIMDT, E. L.; JAVORSKI, C. R.; CASTAGNARA, D. D. Composição químico-bromatológica e perfil de fermentação da silagem de resíduo úmido de fécula de mandioca. Bioscience Journal, Uberlândia, v. 30, n. 2, p. 502-511, 2014.

GONZÁLEZ, F. H. D.; CONCEIÇÃO, T. R.; SIQUEIRA, A. J. S.; ROSA, V. L. Variações sanguíneas de uréia, creatinina, albumina e fósforo em bovinos de corte no Rio Grande do Sul. A Hora Veterinária, Florianópolis, v. 20, p. 59-62, 2000.

GONZÁLEZ, F. H. D.; DÜRR, J. W.; FONTANELI, R. S. Uso do leite para monitorar a nutrição e o metabolismo de vacas leiteiras. Porto Alegre: Biblioteca Setorial da Faculdade de Medicina Veterinária da UFRGS, 2001a. $72 \mathrm{p}$.

GONZÁLEZ, F. H. D.; ORTOLANI, E. L.; BARROS, L.; CAMPOS, R. Avaliação metabólico-nutricional de vacas leiteiras por meio de fluidos corporais. Porto Alegre: Biblioteca Setorial da Faculdade de Medicina Veterinária da UFRGS, 2001b. 72 p.

HUNTINGTON, G. B. Starch utilization by ruminants: from basics to the bunk. Journal of Animal Science, Champaign, IL, v. 75, n. 3, p. 852-867, 1997.

INSTITUTO BRASILEIRO DE GEOGRAFIA ESTATÍSTICA - IBGE. Levantamento sistemático da produção agrícola, Brasil. Brasil - SIDRA, jul. 2013. Acesso em: $<$ http://www.sidra.ibge.gov.br/bda/imprimir/ imprhome.asp?t=5\&u=1>. Acesso em: 16 ago. 2013.

LAMMERS, B. P.; BUCKMASTER, D. R.; HEINRICHS, A. J. A simple method for the analysis of particle sizes of forage and total mixed rations. Journal of Dairy Science, Philadelphia, v. 79, n. 5, p. 922-928, 1996.

LEONEL, M.; CEREDA, P. M.; ROAU, X. Aproveitamento do resíduo da produção de etanol a partir de farelo de mandioca, como fonte de fibras dietéticas.
Ciência e Tecnologia de Alimentos, Campinas, v. 19 n. 2, p. 241-245, 1999.

LIMA, P.; VELOSO, C. M.; SILVA, F. F.; BONOMO, P.; PINHEIRO, A. A.; DUTRA,G. S.; PEREIRA JÚNIOR, I. G.; VELOSO, J. M. C. Bagaço de mandioca (Manihot esculenta, Crantz) na dieta de vacas leiteiras: consumo de nutrientes. Arquivo Brasileiro de Medicina Veterinária e Zootecnia, Belo Horizonte, v. 60, n. 4, p. 1004-1010, 2008.

MARQUES, J. A.; CALDAS NETO, S. F. Mandioca na alimentação animal: parte aérea e raiz. Campo Mourão: CIES, 2002. 28 p.

MARQUES, J. A.; PRADO, I. N.; ZEOULA, L. M. Avaliação da mandioca e seus resíduos industriais em substituição ao milho no desempenho de novilhas confinadas. Revista Brasileira de Zootecnia, Viçosa, MG, v. 29, n. 5, p. 1528-1536, 2000.

MOURO, G. F.; BRANCO, A. F.; MACEDO, F. A. F.; RIGOLON, L. P.; MAIA, F. J.; GUIMARAES, K. C.; DAMASCENO, J. C.; SANTOS, G. T. Substituição do milho pela farinha de mandioca de varredura em dietas de cabras em lactação: produção e composição do leite e digestibilidade dos nutrientes. Revista Brasileira de Zootecnia, Viçosa, MG, v. 31, n. 1, p. 475-483, 2002.

NATIONAL RESEARCH COUNCIL - NRC. Nutrient requirements of dairy cattle. $7^{\text {th }}$. eld. rev. Washington D. C.: National Academy of Sciences, 2001. 381 p.

NOCEK, J. E.; TAMINGA, S. Site of digestion of starch in the gastrointestinal tract of dairy cows and its effect on milk yield and composition. Journal of Dairy Science, Philadelphia, v. 74, n. 10, p. 3598-3629, 1991.

PEREIRA, M. N.; GARRET, E. F.; OETZEL, G. R.; ARMENTANO, L. E. Partial replacement of forage with nonforage fiber sources in lactating cow diets. I. Performance and health. Journal of Dairy Science, Philadelphia, v. 82, n. 12, p. 2716-2730, 1999.

PIRES, A. V.; SUSIN, I.; SANTOS, F. A. P.; MENDES, C. Q.; OLIVEIRA JUNIOR, R. C.; FERNANDES, J. J. R.; SIMAS, J. M. C. Efeito de fontes e formas de processamento do amido sobre o desempenho e o metabolismo do nitrogênio em vacas Holandesas em lactação. Revista Brasileira de Zootecnia, Viçosa, MG, v. 37, n. 8, p. 1456-1462, 2008.

RAMALHO, R. P.; FERREIRA, M. A.; VÉRAS, A. S. C.; LIMA, L. E.; ROCHA, V. R. R. A. Substituição do milho pela raspa de mandioca em dietas para vacas primíparas em lactação. Revista Brasileira de Zootecnia, Viçosa, MG, v. 35, n. 3, p. 1221-1227, 2006.

SANTOS, F. A. P.; HUBER, J. T.; THEURER, C. B. Milk yield and composition of lactating cows fed 
steam-flaked sorghum and graded concentrations of ruminally degradable protein. Journal of Dairy Science, Philadelphia, v. 81, n. 1, p. 215-220, 1998.

SILVA, D. J.; QUEIROZ, A. C. Análise de alimentos: métodos químicos e biológicos. 3. ed. Viçosa, MG: Universidade Federal de Viçosa, 2002. 235 p.

SKLAN, D.; ASHKENNAZI, R.; BRAUN, A.; DEVORIN, A.; TABORI, K. Fatty acids, calcium soaps of fatty acids, and cottonseeds fed to high yielding cows. Journal of Dairy Science, Philadelphia, v. 75, n. 9, p. 2463-2472, 1992.

SVIHUS, B.; UHLEN, A. K.; HARSTAD, O. M. Effect of starch granule structure, associated components and processing on nutritive value of cereal starch: a review. Animal Feed Science and Technology, Amsterdam, v. 122, n. 3-4, p. 303-320, 2005.

THEURER, C. B.; HUBER, J. T.; DELGADOELORDUY, A.; WANDERLEY, R. Invited review: Summary of steam-flaking corn or sorghum grain for lactating dairy cows. Journal of Dairy Science, Philadelphia, v. 82, n. 9, p. 1950-1959, 1999.
VALADARES FILHO, S. C. Nutrição, avaliação de alimentos e tabelas de composição de alimentos para bovinos. In: REUNIÃO ANUAL DA SOCIEDADE BRASILEIRA DE ZOOTECNIA, 37., 2000, Viçosa. Anais... Viçosa: Sociedade Brasileira de Zootecnia, 2000. p. 267-337.

VAN SOEST, P. J. Nutritional ecology of the ruminant. 2. ed. Ithaca: Cornell University Press, 1994. 476 p.

VAN SOEST, P. J.; ROBERTSON, J. B.; LEWIS, B. A. Carbohydrate methodology, metabolism, and nutritional implications in dairy cattle. Journal of Dairy Science, Philadelphia, v. 74, n. 10, p. 3583-3597, 1991.

WALLER, J.; MERCHEN, N.; HANSON, T.; KLOPFENSTEIN, T. Effect of sampling intervals and digesta markers on abomasal flow determinations. Journal of Animal Science, Champaign, IL, v. 50, n. 6, p. 1122-1126, 1980. 